\title{
Impact of the gut microbiome on the genome and epigenome of colon epithelial cells: contributions to colorectal cancer development
}

\author{
Jawara Allen ${ }^{1}$ and Cynthia L. Sears ${ }^{1,2^{*}}$
}

\begin{abstract}
In recent years, the number of studies investigating the impact of the gut microbiome in colorectal cancer (CRC) has risen sharply. As a result, we now know that various microbes (and microbial communities) are found more frequently in the stool and mucosa of individuals with CRC than healthy controls, including in the primary tumors themselves, and even in distant metastases. We also know that these microbes induce tumors in various mouse models, but we know little about how they impact colon epithelial cells (CECs) directly, or about how these interactions might lead to modifications at the genetic and epigenetic levels that trigger and propagate tumor growth. Rates of CRC are increasing in younger individuals, and CRC remains the second most frequent cause of cancer-related deaths globally. Hence, a more in-depth understanding of the role that gut microbes play in CRC is needed. Here, we review recent advances in understanding the impact of gut microbes on the genome and epigenome of CECs, as it relates to CRC. Overall, numerous studies in the past few years have definitively shown that gut microbes exert distinct impacts on DNA damage, DNA methylation, chromatin structure and non-coding RNA expression in CECs. Some of the genes and pathways that are altered by gut microbes relate to CRC development, particularly those involved in cell proliferation and WNT signaling. We need to implement more standardized analysis strategies, collate data from multiple studies, and utilize CRC mouse models to better assess these effects, understand their functional relevance, and leverage this information to improve patient care.
\end{abstract}

\section{Background}

Human gut microbiome composition has recently been associated with a myriad of diseases, ranging from autism and schizophrenia to inflammatory bowel disease and colorectal cancer (CRC) [1-3]. Many of the associations between the gut microbiome and disease implicate both the microbiome composition overall and specific microbial species in disease development; the link between the gut microbiome and cancer is no exception. Several studies show that both the overall gut microbiome composition and microbial organization differ in CRC patients compared to healthy individuals [4-9].

\footnotetext{
* Correspondence: csears@jhmi.edu

${ }^{1}$ Department of Medicine, Johns Hopkins University School of Medicine, Orleans Street, Baltimore, MD 21231, USA

${ }^{2}$ Bloomberg-Kimmel Institute for Immunotherapy and Department of Oncology, Sidney Kimmel Comprehensive Cancer Center, Johns Hopkins Medical Institutions, North Broadway, Baltimore, MD 21231, USA
}

Other studies show that, in some cases, particular microbial species are present more frequently in tumor tissue than in flanking normal tissue throughout the entire progression of disease, from early tumor development to metastasis $[5,7,10-22]$. Table 1 summarizes key features of the major changes in the gut microbiome and the individual microbes associated with CRC.

In an effort to move past correlation into the realm of causation, various microbial communities, and individual microbes, have been tested for their abilities to induce tumor formation in mouse models of CRC. As outlined in Table 1, some studies have used azoxymethane $(\mathrm{AOM})$, a carcinogenic compound that induces colonic epithelial cell (CEC) mutations (largely affecting the WNT pathway), to test whether specific microbial communities impact colon tumorigenesis in mice [23-26]. Other studies have utilized $A p c^{\text {min/+ }}$ mice, a genetic

(c) The Author(s). 2019 Open Access This article is distributed under the terms of the Creative Commons Attribution 4.0 International License (http://creativecommons.org/licenses/by/4.0/), which permits unrestricted use, distribution, and 


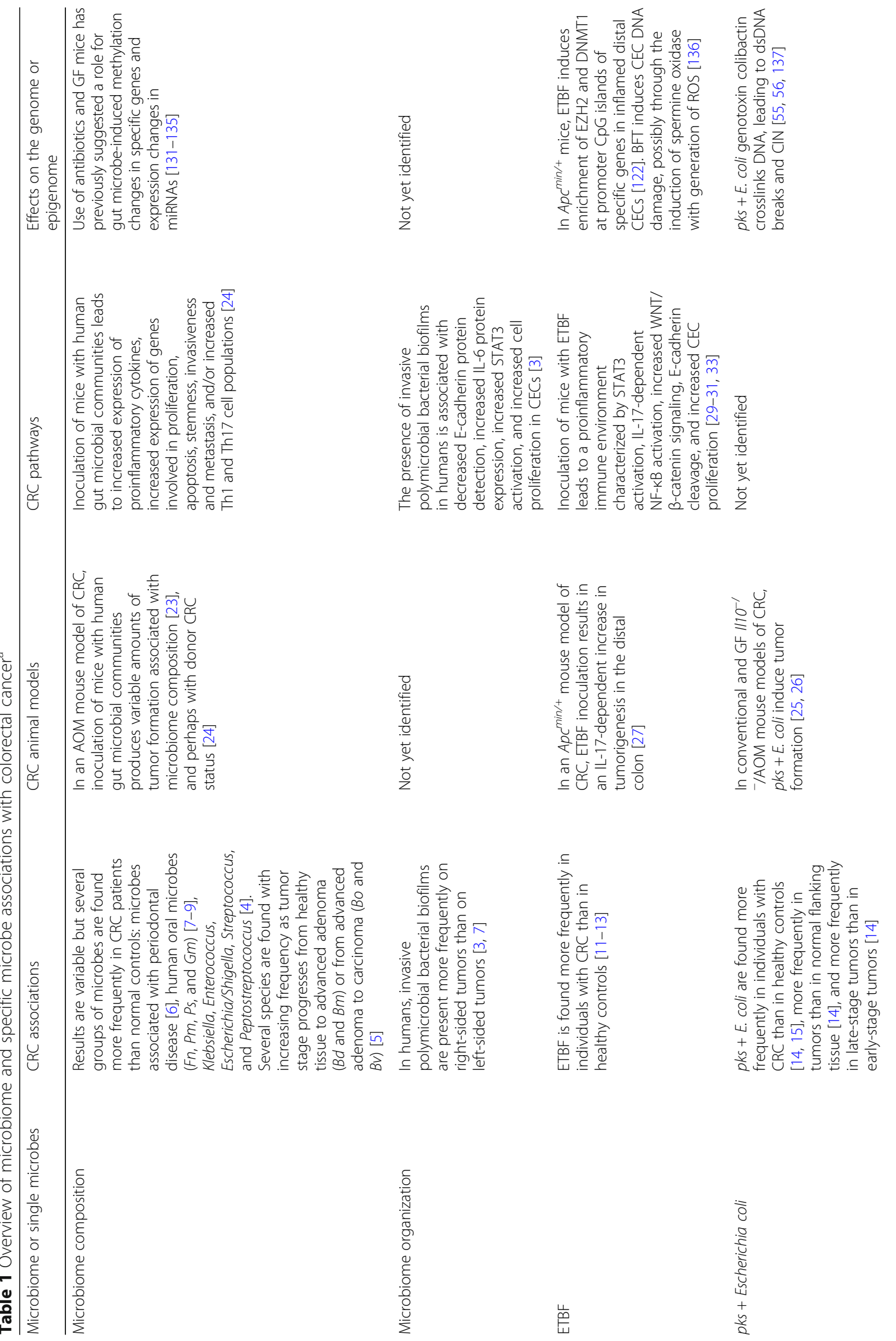




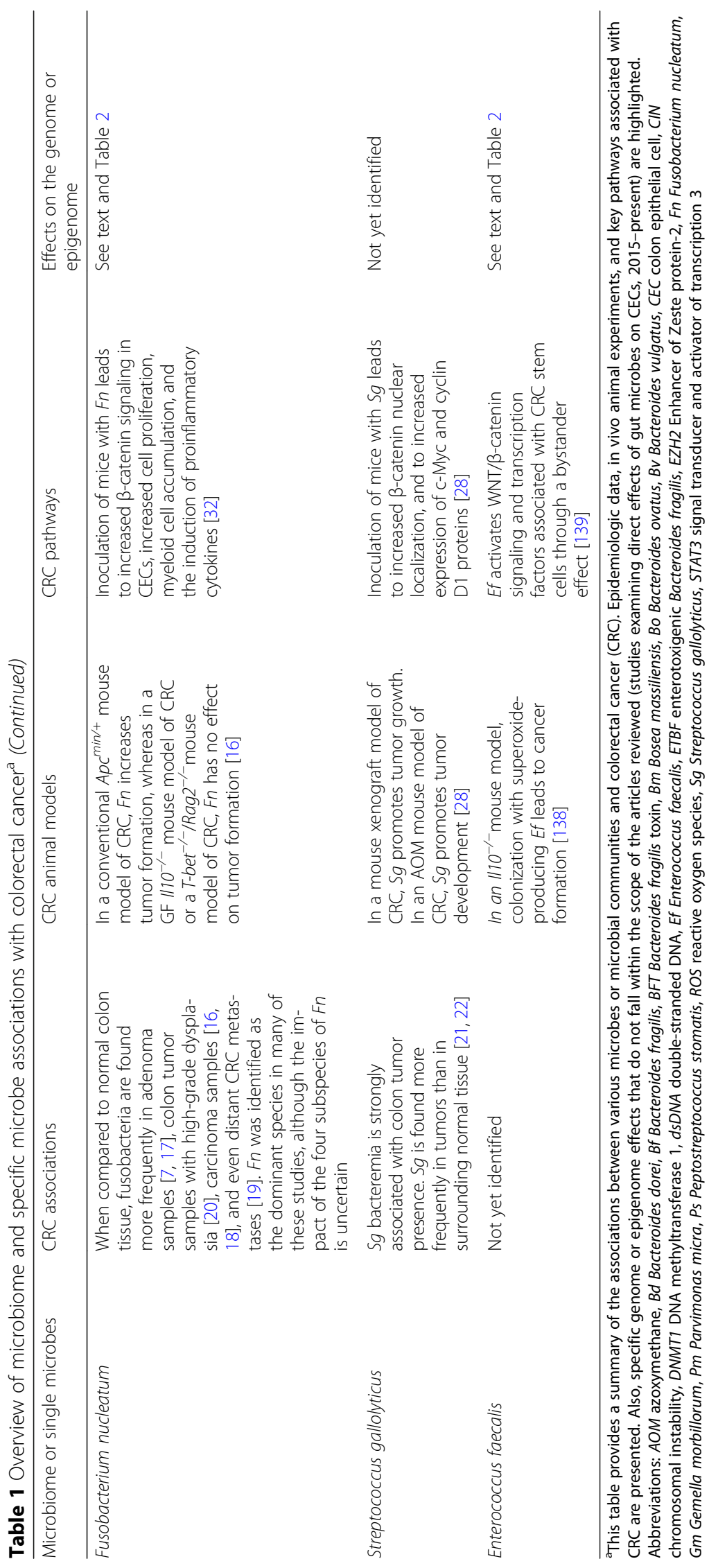


model of CRC in which mice are predisposed to intestinal adenoma formation as a result of a mutation in the $A p c$ gene and increased WNT signaling [16, 27, 28]. These models facilitate dissection of the CEC pathways that are altered by the gut microbiome, and have been used to identify microbe-induced changes in WNT signaling, $\beta$-catenin nuclear localization, IL-6 expression, STAT3 activation, E-cadherin cleavage, cell proliferation, inflammation, and immune cell infiltration [27-33]. To date, we have strong evidence that both microbial community composition and organization and the presence of specific microbes are associated with various stages of CRC development, and that these microbes could initiate tumor formation and contribute to tumor growth in vivo.

Nevertheless, cancer is a disease that is initiated and progresses (via processes including tissue invasion and metastasis) through changes in the genome and epigenome $[34,35]$. So, to establish a direct, causal connection between the gut microbiome and CRC development, we must determine whether and how microbes alter mutation rates, gene methylation, chromatin structure, and/or non-coding RNA expression in CECs. Several epidemiological studies have associated specific bacteria in the gut with tumors that are characterized by DNA hypermethylation [36-39] or by specific mutational patterns [40], strengthening the hypothesis that gut microbes have a role in CRC development through their effects on the genome and epigenome of CECs.

Gut microbes could elicit their effects on the genome or epigenome via direct or indirect mechanisms. There are two key indirect mechanisms. The first is the capacity of gut microbes to induce a pro-carcinogenic inflammatory response [41-43]. The second is the production of secondary metabolites by gut microbes [44-46]. The ability of short chain fatty acids (SCFAs), hydrogen sulfide $\left(\mathrm{H}_{2} \mathrm{~S}\right)$, secondary bile acids, and many other metabolites to impact the genome or epigenome of CECs, to alter rates of CRC progression, and to function as targets for CRC prevention or treatment is tremendously important and has thus been the topic of many recent reviews [47-50]. Overall, SCFAs (such as acetate, propionate, and butyrate) have been shown to function in the suppression of inflammation-for example, downregulation of pro-inflammatory cytokines and induction of $\mathrm{FOXP}^{+} \mathrm{T}$ regulatory cell differentiation-and thus are thought to possess mostly anti-carcinogenic properties. By contrast, $\mathrm{H}_{2} \mathrm{~S}$, secondary bile acids, and other metabolites have been shown to cause DNA damage, and thus are thought to be more pro-carcinogenic [50].

In this review, we focus on examining recent articles (2015-present) that describe the direct effects of bacteria on CECs. We highlight studies that have utilized live bacteria, bacterial communities, or species-specific virulence factors to determine whether microbes can alter the genome or epigenome in ways that directly propel CEC transformation and the clonal expansion that defines CRC (Table 2). We also discuss recent studies in which direct effects of microbial metabolites on the genome or epigenome of CECs have been demonstrated. We anticipate that a more complete understanding of all of these effects will allow us to add microbiome data to the accruing CEC genetic and epigenetic data used to screen for CRC. Moreover, we predict that these data will enable the development of combination strategies for the prevention and treatment of CRC that target: (i) CEC pathways that are altered by genome or epigenome changes; and (ii) the microbiome, for example, via bacteriophage microbiome modulation, targeted antibiotics, and/or specific bacterial vaccines.

\section{The genome}

\section{The gut microbiome and DNA damage}

The majority of spontaneous CRC development follows Knudson's classic two-hit hypothesis [51, 52]. In this model, one mutation in each allele of the $A P C$ gene is needed to initiate tumorigenesis in the colon, and subsequent mutations in additional genes increase the rate of tumor growth and development $[53,54]$. This pattern is seen in both hereditary and spontaneous CRC development, with at least $70-80 \%$ of spontaneous CRC tumors possessing mutations in both $A P C$ alleles [52]. As a result, when examining the impact of gut microbes on CRC development, it is important to determine whether the direct interaction between microbes and CECs can lead not only to DNA damage but also to specific gene mutations that contribute to CRC development.

pks + Escherichia coli are among the most extensively studied genotoxin-producing bacteria. They produce a cyclomodulin toxin called colibactin, which causes DNA double-strand breaks, chromosomal aberrations, and cell cycle arrest in cells in vitro $[55,56]$. Recent studies have delved deeper into colibactin's mechanism of action and have shown that, upon exposure to cells, this genotoxin induces intrastrand DNA crosslinking [57]. This crosslinking is accompanied by a robust ATR-dependent replication stress response [57], in which ATR phosphorylates many proteins that regulate origin of replication firing, cell cycle transitions, and replication fork progression [58]. This response prevents cells with damaged DNA from entering mitosis. In studies conducted by Dejea and colleagues [59], $p k s+E$. coli were found to work synergistically with enterotoxigenic Bacteroides fragilis (ETBF) to cause increased DNA damage and increased tumor formation in a mouse model of CRC. This DNA damage was accompanied by a heightened inflammatory response that was necessary, but not 
Table 2 Summary of recent papers (2015-present) addressing the impact of gut microbes on the colon epithelial cell genome or epigenome

\begin{tabular}{|c|c|c|c|c|}
\hline Key findings & Bacteria studied & Model system & $\begin{array}{l}\text { Relevant CRC genes or } \\
\text { pathways identified }\end{array}$ & $\begin{array}{l}\text { Technique used to examine } \\
\text { genome or epigenome }\end{array}$ \\
\hline \multicolumn{5}{|l|}{ DNA damage } \\
\hline $\begin{array}{l}\text { Colibactin-induced } \\
\text { intrastrand DNA } \\
\text { crosslinking upon exposure } \\
\text { to cells [57] }\end{array}$ & $p k s+E$. coli & HeLa cells & None highlighted & $\begin{array}{l}\text { Cross-linking assay in cells, } \\
\text { acellular DNA-cross-linking } \\
\text { assay }\end{array}$ \\
\hline $\begin{array}{l}\text { pks }+ \text { E. coli worked } \\
\text { synergistically with ETBF to } \\
\text { cause increased DNA } \\
\text { damage and increased } \\
\text { tumor formation in a } \\
\text { mouse model of CRC [59] }\end{array}$ & $p k s+E$. coli and ETBF & Mice & None highlighted & Immunohistochemistry \\
\hline $\begin{array}{l}\text { When inoculated with } \\
\text { ETBF, } A p c^{\mathrm{min} /+} / \mathrm{Msh}^{-/-} \\
\text {mice produced more } \\
\text { tumors than } A p c^{\text {min/+ }} \text { mice. } \\
\text { The increase in tumor } \\
\text { burden was not seen in } \\
\text { the absence of ETBF } \\
\text { inoculation, suggesting } \\
\text { that MMR proteins are } \\
\text { important in preventing } \\
\text { tumorigenesis after ETBF } \\
\text { infection [61] }\end{array}$ & ETBF & Mice & None highlighted & Transgenic mouse model \\
\hline $\begin{array}{l}\text { CECs exposed to } \\
\text { macrophages that were } \\
\text { previously exposed to } \\
\text { E. faecalis showed an } \\
\text { increased rate of } \\
\text { mutagenesis and an } \\
\text { increased rate of } \\
\text { aneuploidy and } \\
\text { chromosomal translocation, } \\
\text { indicative of CIN [63] }\end{array}$ & E. faecalis & $\begin{array}{l}\text { Young adult mouse } \\
\text { colonic (YAMC) ECs }\end{array}$ & $\begin{array}{l}\text { Several cancer driver genes, } \\
\text { including Arid1b, Cdkn2a, } \\
\text { Daxx, Gata3, Map3k1, Notch1, } \\
\text { Pten, Smad2 and others }\end{array}$ & Mutant fraction assay, FACS \\
\hline \multicolumn{5}{|l|}{ Methylation } \\
\hline $\begin{array}{l}\text { In a porcine model, in } \\
\text { which premature infant } \\
\text { pigs were given antibiotics } \\
\text { immediately after birth, } 80 \\
\text { DMRs were identified and } \\
\text { were associated with } \\
\text { genes involved in } \\
\text { phagocytosis, the innate } \\
\text { immune response, and } \\
\text { other pathways [73] }\end{array}$ & $\begin{array}{l}\text { Antibiotic-treated porcine } \\
\text { gut microbiome }\end{array}$ & Premature infant pigs & $\begin{array}{l}\text { Pathways related to innate } \\
\text { immune response and } \\
\text { phagocytosis }\end{array}$ & RRBS, BSP \\
\hline $\begin{array}{l}\text { Treatment of human } \\
\text { intestinal ECs with } \\
\text { Lactobacillus acidophilus, } \\
\text { Bifidobacterium infantis, and } \\
\text { Klebsiella species resulted in } \\
\text { methylation changes in } \\
\text { several hundred genes of } \\
\text { interest [74] }\end{array}$ & $\begin{array}{l}\text { L. acidophilus, B. infantis } \\
\text { and Klebsiella species }\end{array}$ & $\begin{array}{l}\text { Human intestinal EC lines } \\
\text { (H4 and NCM460) }\end{array}$ & $\begin{array}{l}\text { Pathways related to } \\
\text { nucleotide binding } \\
\text { (immature ECs) and } \\
\text { chromatin organization } \\
\text { (mature ECs) }\end{array}$ & $\begin{array}{l}\text { Infinium Human Methylation } \\
450 \text { BeadChip }\end{array}$ \\
\hline $\begin{array}{l}\text { Fecal microbial transplant } \\
\text { to reintroduce microbes }\end{array}$ & Murine gut microbiome & Mice & None highlighted & Bisulfite pyrosequencing \\
\hline
\end{tabular}

into GF mice resulted in

increased gene

methylation [75] 
Table 2 Summary of recent papers (2015-present) addressing the impact of gut microbes on the colon epithelial cell genome or epigenome (Continued)

\begin{tabular}{|c|c|c|c|c|}
\hline Key findings & Bacteria studied & Model system & $\begin{array}{l}\text { Relevant CRC genes or } \\
\text { pathways identified }\end{array}$ & $\begin{array}{l}\text { Technique used to examine } \\
\text { genome or epigenome }\end{array}$ \\
\hline $\begin{array}{l}\text { The gene methylation } \\
\text { status of GF mice differed } \\
\text { from that of conventional } \\
\text { mice. The number of } \\
\text { genes with changes in both } \\
\text { gene expression and } \\
\text { methylation status } \\
\text { increased as mice aged [76] }\end{array}$ & Murine gut microbiome & Mice & $\begin{array}{l}\text { Pathways related to cellular } \\
\text { proliferation or regeneration } \\
\text { (Pik3cd, Rb1, Grb10, Plagl1, } \\
\text { Nfix, Tab3) and immune } \\
\text { response (Atp7a, Atf4, Bcl3) }\end{array}$ & RRBS \\
\hline $\begin{array}{l}\text { ETBF-induced tumors } \\
\text { contained more } \\
\text { hypermethylated DMRs } \\
\text { and fewer hypomethylated } \\
\text { DMRs than spontaneous } \\
\text { tumors [61] }\end{array}$ & ETBF & Mice & $\begin{array}{l}\text { Hoxa5, Polg, Runx1, Runx3, } \\
\text { CD37, Stx11, Tceb2, Lgr6, Cdx1, } \\
\text { and Fut4 genes }\end{array}$ & $\begin{array}{l}\text { MBD-seq, pyrosequencing, } \\
\text { qMSP }\end{array}$ \\
\hline \multicolumn{5}{|l|}{ Chromatin structure } \\
\hline $\begin{array}{l}\text { Investigators found no } \\
\text { differential DNase } \\
\text { hypersensitivity sites in the } \\
\text { jejunum of GF mice. They } \\
\text { did, however, find changes } \\
\text { in the histone marks } \\
\text { H3K4me1 and H3K27ac, } \\
\text { which are generally } \\
\text { enriched at poised or } \\
\text { active enhancers, } \\
\text { respectively [87] }\end{array}$ & Murine gut microbiome & Mice & $\begin{array}{l}\text { Transcription factors } \\
\text { belonging to the IRF family, } \\
\text { STAT family, and ETS family }\end{array}$ & DNase-seq, ChIP-seq \\
\hline $\begin{array}{l}\text { Several hundred promoters } \\
\text { and enhancers lost } \\
\text { rhythmicity after antibiotic } \\
\text { treatment, and a near equal } \\
\text { number gained de novo } \\
\text { rhythmic behavior [92] }\end{array}$ & $\begin{array}{l}\text { Antibiotic-treated murine } \\
\text { gut microbiome }\end{array}$ & Mice & None highlighted & ChIP-seq \\
\hline $\begin{array}{l}\text { Bacterial presence resulted } \\
\text { in numerous changes in } \\
\text { histone acetylation and } \\
\text { methylation in the } \\
\text { proximal colon tissue of GF } \\
\text { mice. SCFAs produced by } \\
\text { gut microbes might have } \\
\text { mediated this effect [93] }\end{array}$ & Murine gut microbiome & Mice & None highlighted & $\begin{array}{l}\text { Electrospray ionization } \\
\text { tandem mass spectrometry }\end{array}$ \\
\hline $\begin{array}{l}\text { The location of H3K4 } \\
\text { methylation marks was } \\
\text { modified when gut } \\
\text { microbes colonized GF } \\
\text { mice [94] }\end{array}$ & Murine gut microbiome & Mice & $\begin{array}{l}\text { Genes involved in } \\
\text { maintaining the innate } \\
\text { mucosal barrier, ROS } \\
\text { generation, ephrin signaling, } \\
\text { and others }\end{array}$ & ChIP-seq \\
\hline $\begin{array}{l}\text { In mice treated with } \\
\text { antibiotics for } 3 \text { days, } \\
\text { H3K18 crotonylation in the } \\
\text { colon was decreased. This } \\
\text { was associated with a }\end{array}$ & $\begin{array}{l}\text { Antibiotic-treated murine } \\
\text { gut microbiome }\end{array}$ & $\begin{array}{l}\text { Mice, mouse small } \\
\text { intestinal enteroids, } \\
\text { human CRC cell lines } \\
\text { (HCT116) }\end{array}$ & $\begin{array}{l}\text { Pathways related to } \\
\text { endometrial cancer, prostate } \\
\text { cancer, pancreatic cancer, } \\
\text { CRC, TGF- } \beta \text { signaling and } \\
\text { stem cell pluripotency }\end{array}$ & ChIP-seq \\
\hline
\end{tabular}

concomitant decrease in

HDAC2 protein expression,

which was mediated by

the SCFAs butyrate and

crotonate. These SCFAs

promote H3K18

crotonylation by inhibiting

HDACs [96] 
Table 2 Summary of recent papers (2015-present) addressing the impact of gut microbes on the colon epithelial cell genome or epigenome (Continued)

\begin{tabular}{|c|c|c|c|c|}
\hline Key findings & Bacteria studied & Model system & $\begin{array}{l}\text { Relevant CRC genes or } \\
\text { pathways identified }\end{array}$ & $\begin{array}{l}\text { Technique used to examine } \\
\text { genome or epigenome }\end{array}$ \\
\hline \multicolumn{5}{|l|}{ Non-coding RNAs } \\
\hline $\begin{array}{l}\text { Using GF mice, the } \\
\text { presence of gut microbes } \\
\text { was associated with } \\
\text { decreased production of } \\
\text { miRNAs, which were } \\
\text { shown to be produced by } \\
\text { intestinal ECs, goblet cells } \\
\text { and Paneth cells [107] }\end{array}$ & Murine gut microbiome & Mice & None highlighted & NanoString nCounter \\
\hline $\begin{array}{l}\text { Absence (GF mice) of the } \\
\text { gut microbiota resulted in } \\
\text { lower levels of expression } \\
\text { of the miRNAs let-7b, } \\
\text { miR-141, and miR-200a. } \\
\text { Depletion (antibiotic-treated } \\
\text { rats) of gut microbiota } \\
\text { resulted in lower levels of } \\
\text { miRNAs let-7b, miR-141, } \\
\text { miR-200a, and miR-1224 } \\
\text { after } 6 \text { weeks of } \\
\text { treatment [108] }\end{array}$ & $\begin{array}{l}\text { Murine gut microbiome, } \\
\text { antibiotic-treated murine } \\
\text { gut microbiome }\end{array}$ & Mice, rats & $\begin{array}{l}\text { let-7b, miR-141, miR-200a, } \\
\text { and miR-1224 }\end{array}$ & qRT-PCR \\
\hline $\begin{array}{l}\text { miR-21-5p was expressed } \\
\text { at higher levels in the } \\
\text { small and large intestine of } \\
\text { conventional mice than in } \\
\text { GF mice. Exposing HT-29 } \\
\text { and SW480 cells (two CRC } \\
\text { cell lines) to Bacteroides } \\
\text { acidifaciens type A43 and } \\
\text { Lactobacillus johnsonii } 129 \\
\text { resulted in an upregulation } \\
\text { of miR-21-5p [112] }\end{array}$ & $\begin{array}{l}\text { Murine gut microbiome, } \\
\text { B. acidifaciens type A43 } \\
\text { and L. johnsonii } 129\end{array}$ & $\begin{array}{l}\text { Mice, human CRC cell } \\
\text { lines (HT-29, SW480) }\end{array}$ & miR-21-5p & Microarray \\
\hline $\begin{array}{l}19 \text { miRNAs were } \\
\text { differentially expressed in } \\
\text { IESCs of GF mice when } \\
\text { compared to } \\
\text { conventionalized mice. } \\
\text { miR-375-3p } \\
\text { was downregulated in } \\
\text { conventionalized } \\
\text { mice [115] }\end{array}$ & Murine gut microbiome & $\begin{array}{l}\text { Mice, mouse small } \\
\text { intestinal enteroids }\end{array}$ & $\operatorname{miR}-375-3 p$ & RNA-seq \\
\hline $\begin{array}{l}\text { Several miRNAs were } \\
\text { downregulated in } \\
\text { Fusobacterium nucleatum- } \\
\text { rich tumor samples from } \\
\text { patients with recurrent CRC. } \\
\text { A CRC xenograft model was } \\
\text { used to show that F. } \\
\text { nucleatum causes resistance } \\
\text { to oxaliplatin and 5-FU via } \\
\text { downregulation of miR-4802 } \\
\text { and miR-18a* [117] }\end{array}$ & F. nucleatum & $\begin{array}{l}\text { Mice, CRC cell lines } \\
\text { (HCT116 and HT29) }\end{array}$ & $\begin{array}{l}\text { miR-4802 (newly associated } \\
\text { with } C R C \text { ) and miR-18a* } \\
\text { (belongs to the miR-17-92 } \\
\text { cluster) }\end{array}$ & RNA-seq \\
\hline $\begin{array}{l}\text { IncRNAs in the mouse } \\
\text { duodenum, jejunum, } \\
\text { ileum, and colon were } \\
\text { altered in GF mice when } \\
\text { compared to conventional } \\
\text { mice }[118]\end{array}$ & Murine gut microbiome & Mice & $\begin{array}{l}\text { Pathways related to GPCR } \\
\text { signaling and TGF signaling }\end{array}$ & RNA-seq \\
\hline
\end{tabular}


Table 2 Summary of recent papers (2015-present) addressing the impact of gut microbes on the colon epithelial cell genome or epigenome (Continued)

\begin{tabular}{|c|c|c|c|c|}
\hline Key findings & Bacteria studied & Model system & $\begin{array}{l}\text { Relevant CRC genes or } \\
\text { pathways identified }\end{array}$ & $\begin{array}{l}\text { Technique used to examine } \\
\text { genome or epigenome }\end{array}$ \\
\hline $\begin{array}{l}\text { When GF mice were } \\
\text { reconstituted with normal } \\
\text { mouse microbiota or with } \\
\text { E. coli alone, fairly distinct } \\
\text { changes in IncRNA } \\
\text { signatures occurred, with } \\
\text { only } 8 \% \text { of the } \\
\text { differentially expressed } \\
\text { IncRNAs overlapping [119] }\end{array}$ & $\begin{array}{l}\text { Murine gut microbiome, } \\
\text { E. coli }\end{array}$ & Mice & None highlighted & $\begin{array}{l}\text { Affymetrix mouse exon } \\
\text { microarray }\end{array}$ \\
\hline
\end{tabular}

Abbreviations: BSP bisulfite sequencing PCR, CEC colon epithelial cell, ChIP chromatin immunoprecipitation, CIN chromosomal instability, DMR differentially methylated region, ETBF enterotoxigenic Bacteroides fragilis, EC epithelial cell, ETS e26 transformation specific, GF germ-free, FACS fluorescence-activated cell sorting, GPCR G-protein-coupled receptor, HDAC histone deacetylase, IESC intestinal epithelial stem cell, IRF interferon regulatory factor, IncRNA long non-coding RNA, MBD methyl CpG binding domain, miRNA microRNA, MMR mismatch repair, GMSP quantitative methylation-specific PCR, ROS reactive oxygen species, RRBS reduced representation bisulfite sequencing, SCFA short chain fatty acid, STAT signal transducer and activator of transcription, YAMC young adult mouse colonic

sufficient, for increased colon tumor formation. The increased tumorigenesis was also highly dependent on the presence of both colibactin and B. fragilis toxin (BFT). Together, this evidence points to a direct correlation between these bacterial toxins, an increased inflammatory response, DNA damage, and tumor formation, but no studies to date have determined whether colibactin or BFT directly induces disease-initiating or disease-promoting DNA mutations in CECs.

Studies conducted using E. coli and ETBF provide clues as to how we can begin to dissect out the effects of DNA damage caused by their secreted toxins. In one study, Maddocks and colleagues [60] showed that enteropathogenic E. coli (EPEC) deplete the mismatch repair proteins of host cells, leading to an increased mutation frequency, as measured using an artificially inserted microsatellite. The effect was mediated by an EPEC-secreted protein (EspF) that targets the mitochondria of CECs and induces post-translational modifications of mismatch repair proteins [60]. In another study, Maiuri and colleagues [61] showed that, when inoculated with ETBF, $A p c^{\min /+} / M s h 2^{-/-}$mice produced more tumors than $A p c^{m i n /+}$ mice with intact Msh2 mismatch repair proteins. The increase in tumor burden was not seen in the absence of ETBF inoculation, suggesting that mismatch repair proteins play an important role in preventing tumorigenesis after ETBF colonization [61]. These approaches can be modified and used in vitro to determine whether bacterial toxins such as BFT and colibactin can directly cause DNA mutations in CECs. These methods only identify mismatch-repair-based increases in mutation rates, but other more generalized strategies are also available. The hypoxanthine phosphoribosyltransferase (HPRT)-forward mutation assay can be used to test the general mutation rate that is induced by a given compound. In this assay, the cells that are used contain one copy of the HPRT1 gene. When grown in the presence of 6-thioguanine (6-TG), only cells that have acquired a mutation in their HPRT1 gene are able to survive. So, by counting the number of cells that are alive after 6-TG treatment and comparing it to untreated controls, a general mutation frequency can be determined [62]. A similar assay was used by Wang and colleagues [63] to show that macrophages that are exposed to Enterococcus faecalis-induced mutations in a mouse colonic epithelial cell line.

Chromosomal instability (CIN) in epithelial cells is another mechanism that contributes to tumor formation. CIN has been identified in nearly all cancers, including CRC $[53,64,65]$. In order to determine whether bacteria can induce CIN in epithelial cells, immune cells have been used as an intermediary. Specifically, Wang and colleagues [63] first cultured macrophages in the presence of E. faecalis. They then exposed CECs to those macrophages and found an increased rate of aneuploidy and chromosomal translocation, indicative of CIN. These CECs were subsequently injected into the flank of NOD/ SCID mice, which lack functioning $\mathrm{T}$ cells, $\mathrm{B}$ cells, and NK cells, and only CECs that had been exposed to the macrophages or a control carcinogen formed a tumor mass. Gene expression profiling of these masses revealed altered gene expression of at least three 'driver genes' in each sample [63]. This study highlights a novel microbialmacrophage interaction that induces pro-carcinogenic genome changes. Although these studies do not demonstrate direct effects of bacteria that lead to CIN in CECs, they do outline a methodology for future experiments; bacteria such as pks + E. coli, ETBF, and Fusobacterium nucleatum could be exposed to CECs and the cells could then be analyzed for chromosomal translocations and aneuploidy.

Whole-genome sequencing can also be used to measure mutation frequency and to observe pathogen-specific mutational patterns directly. In a study conducted by Szikriszt and colleagues [66], cisplatin treatment of a chicken lymphoblastic cell line was shown to induce primarily $\mathrm{C}>\mathrm{A}$ 
mutations, a pattern found frequently in aflatoxin-induced cancers [66]. Importantly, the specific signature identified after cisplatin exposure differed when human cell lines were used $(\mathrm{C}>\mathrm{T}$ instead of $\mathrm{C}>\mathrm{A}$ mutations were most frequent) [67], which emphasizes the importance of relevant model selection in experimental design. These experiments would be particularly informative in models where bacterial communities, such as biofilms, induce tumor formation, as the causal bacteria are difficult to identify. Knowing the mutational signature caused by the biofilm may narrow down the list of driver organisms and provide us with a new target for screening.

\section{The epigenome}

\section{The gut microbiome and DNA methylation}

DNA methylation generally describes the addition of a methyl group $\left(\mathrm{CH}_{3}\right)$ to a cytosine residue that precedes a guanine residue in DNA (termed CpG islands, often at or near the start site of gene transcription) [68]. The effects of DNA methylation on cancer development have been examined extensively. Two of the first studies showed both global and gene-specific DNA hypomethylation in cancer [69, 70]. Both hypomethylation and hypermethylation have been linked to CRC development, but the mechanisms by which they contribute to cancer development differ. DNA hypomethylation is generally thought to lead to tumorigenesis via one of three pathways: chromosomal instability, loss of imprinting, or reactivation of transposable elements [71]. Hypermethylation, on the other hand, is believed to lead to the decreased expression of tumor suppressor genes. Since the early studies, data have accrued to show that methylation differences play a major role in the initiation and progression of many types of cancer [72]. Much of this research has focused on CRC, where CpG island hypermethylation of $M L H 1, R A R B 2, C D K N 2 A$, and other genes has been linked to tumor formation and growth $[68,71]$.

The question has been raised as to whether the gut microbiota are among the stimuli that can alter the balance of DNA methylation in CECs, and thus represent an avenue of investigation to determine whether there is a relationship between gut microbes, gene methylation, and the development of CRC. Two recent studies, using non-mouse models, have investigated this question. Pan and colleagues [73] used a porcine model, in which premature infant pigs were given antibiotics immediately after birth, to investigate the effect of early bacterial colonization in the gut on gene methylation. They found more than 80 differentially methylated regions (DMRs) in the distal small intestine and associated these regions with genes involved in phagocytosis, the innate immune response, and other pathways. Cortese and colleagues [74] used mature or immature human intestinal epithelial cell lines to investigate the impact of specific microbes on gene methylation status. This study showed that treatment of these cells with probiotic species (Lactobacillus acidophilus and Bifidobacterium infantis) or Klebsiella species resulted in methylation changes in several hundred genes of interest [74]. In immature epithelial cells, the common differentially methylated genes belonged to nucleotide-binding pathways, whereas in mature cells, the common differentially methylated genes belonged to chromatin organization pathways. Importantly, the majority of changes were specific to the bacteria used [74].

Other studies have looked to mice in order to tease out the relationship between the gut microbiome and CEC gene methylation status. $\mathrm{Yu}$ and colleagues [75] found that the presence of gut microbes led to an increase in the 3' CpG island methylation of specific genes, which correlated with increased gene expression, suggesting a functional role for these changes. This result was corroborated when germ-free mice were conventionalized using fecal microbial transplants and the 3' CpG island methylation status of two genes (B4galnt1 and Phospho1) was examined [75]. A similar study showed that the methylation status of the CECs of germ-free mice differed from that in conventional mice, and that many of the affected genes are frequently mutated in CRC [76]. For example, the proto-oncogene $B c l 3$ was hypomethylated and showed increased gene expression in conventional mice, whereas the tumor suppressor gene $R b 1$ showed decreased gene expression in conventional mice. Although the difference in methylation status between germ-free mice and conventional mice seemed to wane as the mice aged, the number of genes with changes in both gene expression and methylation status increased as the mice aged, suggesting a decreased overall effect of gut microbes on gene methylation with time, but perhaps an increased functional effect [76].

The studies discussed so far have all examined the effects of microbes on methylation in normal CECs, but they did not examine these changes in transformed cells. One recent study has begun to address this knowledge gap. Maiuri and colleagues [61] compared the methylation profile of spontaneous tumors and ETBF-induced tumors in the distal colon of $\mathrm{Apc}^{\mathrm{min} / \mathrm{+}}$ mice. They found that ETBF-induced tumors contained more hypermethylated DMRs and fewer hypomethylated DMRs than spontaneous tumors. Furthermore, many of the hypermethylated DMRs were associated with the CpG islands of genes with known tumor-suppressive functions, such as Hoxa5, Polg, Runx1, Runx3, CD37, Stx11, Tceb2, Lgr6, Cdx1, and Fut4 [61]. The expression of several of these genes was also reduced, but whether BFT induced these changes directly through interaction with CECs or indirectly via induced mucosal immune responses was not determined.

More studies are needed to better understand how methylation changes that are induced by specific 
microbes and their toxins contribute to CRC development. Initial experiments should focus on determining whether presumably health-promoting probiotic species, such as Lactobacillus acidophilus, have a common impact on methylation in CECs that is distinct from the signature induced by pathogenic bacteria. Furthermore, several studies have shown that butyrate can affect both the methylation of DNA globally [77, 78] and the expression of genes that function in DNA methylation or demethylation pathways $[79,80]$. Because most of these experiments have been conducted in vitro using nonCEC lines and have only examined the effects of butyrate in isolation, in vivo studies should be conducted to determine whether butyrate-producing gut microbes can alter DNA methylation in CECs. Finally, more focus should also be placed on effects that are induced by specific bacterial toxins as strategies to detect, alter, or induce protective immunity to these toxins can be utilized more readily in the clinic.

\section{The gut microbiome and chromatin structure}

In the nucleus, DNA is wrapped around histones, which are protein complexes composed of eight subunits. Each histone is made up of two copies each of H2A, H2B, H3, and $\mathrm{H} 4$ subunits, and the DNA-histone complex is referred to as a nucleosome. In general, the nucleus can be divided into regions of heterochromatin (areas in which nucleosomes are packed tightly together) or euchromatin (areas in which nucleosomes are more loosely packed). Areas of heterochromatin tend to be less transcriptionally active whereas areas of euchromatin tend to be more transcriptionally active. The location of histones is tightly regulated by a number of proteins and enzymes that modify the histones or serve as docking sites for other proteins that recognize those modifications [81]. Histone modifications include the methylation, acetylation, or phosphorylation of various residues, among others. Each modification has a unique impact on chromatin structure. For example, the acetylation of histone lysine residues is involved in transcriptional regulation and DNA repair. Histone acetylation and deacetylation are regulated by histone acetyltransferases, which acetylate histones, and histone deacetylases (HDACs), which remove acetyl groups from histones, respectively. Mutations in enzymes that belong to each of these groups have been found in cancer. HDAC inhibitors have already been approved for the treatment of hematologic malignancies, and growing evidence suggests they might be useful in CRC too [81, 82].

Much of the research surrounding the gut microbiome, CRC, and chromatin has focused on the role of butyrate as a HDAC inhibitor. The impact of butyrate has been explored in CRC in a number of studies, most of which show that it plays a protective role $[47-49,83]$, whereas other studies have supported a stimulatory role [84]. The most recent in vivo experiments to analyze the effects of butyrate on colon tumor formation used an $\mathrm{AOM} /$ dextran sodium sulfate (DSS) model of CRC to show that germ-free mice that were inoculated with the butyrate-producing bacterium Butyrivibrio fibrisolvens and given a high fiber diet were mostly protected from tumor formation. Importantly, mice given the bacterium alone or a high fiber diet alone were not protected, whereas mice given a mutant strain of $B$. fibrisolvens that produced lower levels of butyrate had intermediate protection from tumor formation [85]. Mechanistically, the tumors of mice given B. fibrisolvens and a high fiber diet had higher levels of histone subunit H3 acetylation, supporting the role of butyrate as a HDAC inhibitor. The role of butyrate in tumor formation and histone deacetylation has been well-studied and can be used to imply the potential impacts of the microbial community on histone deacetylation, but research on the direct effect of gut microbes on global chromatin structure and on the modulation of other histone marks is just beginning to pick up steam.

In an effort to expand our understanding of the effects of gut microbes on global chromatin structure, Camp and colleagues [86] examined the chromatin landscape of intestinal epithelial cells isolated from the ileum and colon of germ-free and conventionally reared mice. Surprisingly, using a modified DNase-seq hypersensitivity assay, they found no correlation between the presence of bacteria and chromatin accessibility. A more recent study looking at intestinal epithelial cells isolated from the jejunum of germ-free and conventional mice found similar results [87], suggesting rather definitively that gut microbes do not routinely induce changes in global chromatin accessibility. These results do not, however, rule out the potential impact of specific microbes or microbial communities on chromatin structure locally. Indeed, more site-specific analyses, performed by both Camp et al. [86] and Davison et al. [87], revealed greater accessibility of specific transcription factor binding sites in conventional mice. Both groups identified an upregulation in the accessibility of binding sites for transcription factors in the STAT (signal transducer and activator of transcription), IRF (interferon regulatory factor), and ETS (e26 transformation specific) families, each of which has been implicated in CRC progression [88-90]. Furthermore, many of these transcription factors were also identified by Richards and colleagues [91] as being differentially expressed after co-culture of CECs with gut bacteria. Taken together, these studies suggest that microbes alter the chromatin structure in specific regions, and that these changes have a large impact on the expression of genes that are known to be dysregulated in CRC. 
Other studies examining the impact of the gut microbiome on chromatin structure in mice have investigated specific histone modifications. By assaying the location of multiple histone modifications using ChIP-Seq after the antibiotic treatment of mice, Thaiss and colleagues [92] showed that several hundred host gene promoters and enhancers lost rhythmicity following antibiotic treatment, and that a near equal number gained de novo rhythmic behavior. In other words, some mouse genes that display a diurnal pattern of promoter or enhancer chromatin structure no longer displayed this pattern upon antibiotic treatment. The relationship between these changes and CRC is uncertain, but as hundreds of genes were changed, these data need to be mined to determine whether the gut-microbiome-sensitive rhythmic changes in chromatin structure are related to CRC or other diseases. Krautkramer and colleagues [93] examined the proximal colon tissue of germ-free and conventional mice, and found that bacterial presence resulted in numerous changes in histone acetylation and methylation, but direct effects on CECs were not examined. For example, the amount of single acetylated lysine on histone subunit $\mathrm{H} 3$ was elevated in the proximal colon tissue of germ-free mice compared to conventional mice, whereas the amount of double acetylated lysine was reduced [93]. Furthermore, supplementation of the germ-free mouse diet with several SCFAs (acetate, propionate, and butyrate) resulted in a histone profile that more closely resembled that of conventional mice, suggesting that these metabolic byproducts of gut microbes induce histone modifications [93]. The functional implications of these changes in histone profile were assessed by examining gene-expression changes in the hepatocytes of germ-free and conventional mice. As expected, the identified pathways mostly related to metabolism. In future experiments, gene expression in CECs should be examined to determine whether these histone profile changes might contribute to CRC development.

Kelly and colleagues [94] also recently identified a connection between the gut microbiome and certain histone modifications. Specifically, the location of histones with a H3K4 methylation mark was shown to be modified by the presence of gut microbes. Because the location of histone H3 subunits was analyzed along with the presence or absence of $\mathrm{K} 4$ methylation marks, the authors were able to associate the changes with specific genes. This analysis revealed an abundance of genes that belonged to pathways associated with inflammatory bowel disease. Importantly, many of these genes and pathways are also associated with cancer (that is, genes involved in maintaining the innate mucosal barrier, reactive oxygen species generation, or ephrin signaling), so although the authors did not highlight a link to cancer in their findings, their results can be readily applied to better understand how gut microbes affect histone methylation at genes that are known to be dysregulated in CRC [94].

More novel histone modifications have also been associated with gut microbes. Histone crotonylation is the addition of crotonyl groups to a lysine residue of a histone subunit [95]. Crotonylation on lysine 18 of the histone subunit $\mathrm{H} 3(\mathrm{H} 3 \mathrm{~K} 18 \mathrm{cr})$ is a common histone mark in the colon. Moreover, increased crotonylation at H3K18 is associated with the increased expression of genes that are linked to multiple cancers, including CRC [96]. H3K18 crotonylation in the colon decreased in mice treated with antibiotics for three days. This decrease was associated with a concomitant decrease in SCFAs and HDAC2 protein expression. Subsequent experiments showed that the SCFAs butyrate and crotonate promoted $\mathrm{H} 3 \mathrm{~K} 18$ crotonylation by inhibiting HDACs [96].

As the number of known post-translational histone modifications continues to increase [95], these results suggest a burgeoning role for these modifications in gut microbiome-CRC interactions, and perhaps potential new targets for intervention. Moreover, mouse models that test the tumorigenic effect of gut microbes or microbial communities are being used extensively, and thus should be employed to determine whether microbeinduced changes in specific histone modifications or the accessibility of specific transcription factor binding sites affects CRC pathogenesis.

\section{The gut microbiome and non-coding RNAs}

Non-coding RNAs (ncRNAs) are RNA molecules that are transcribed from DNA but not translated into protein. They are generally classified into two groups: small non-coding RNAs (snRNAs) and long non-coding RNAs (lncRNAs) [97]. The most commonly studied snRNAs are microRNAs (miRNAs), which are approximately 22 nucleotides long [98]. By contrast, lncRNAs are ncRNAs that are always greater than 200 nucleotides in length, although some are much larger. MicroRNAs regulate protein-coding gene expression by binding to the 3' UTR of mRNA molecules, causing repressed translation and encouraging the degradation of target mRNAs [99]. By contrast, lncRNAs generally regulate protein-coding gene expression by one of several mechanisms (for example, by acting as a scaffold for histone-modifying complexes, inhibiting the binding of transcription factors by direct binding to the transcription factors themselves or to their DNA targets, directly binding RNA polymerase 2, or binding and sequestering miRNAs) [100].

Dysregulation of both miRNAs and lncRNAs has been associated with CRC. Early studies identified a correlation between increased expression of particular miRNAs and the proto-oncogene $c-M y c$ [101]. More recent studies have 
shown that miRNAs can drive the transformation from adenoma to adenocarcinoma [102], and that the microRNA 17/92 cluster can regulate the expression of common CRC-associated genes, including BCL3 and PTEN [103, 104]. Long ncRNAs, including HOTAIR, CCAT, MALAT-1, H19, and many others, have been associated with CRC development, invasion, and metastasis and with early diagnosis and prognosis [105]. Interestingly, most lncRNAs are also associated with other cancers, suggesting that their functions span several different pathways and cell types.

The gut microbiome has been shown to regulate the expression of protein-coding genes in CECs $[91,92,106]$, so it is not unreasonable to think that the gut microbiome might also regulate the expression of ncRNAs. Most studies to date have used germ-free and conventional mice to determine how lncRNA and miRNA expression differs in the presence of gut microbes. Using NanoString technology to examine the fecal miRNA profile of germ-free mice, conventional mice, and antibiotic-treated mice, Liu and colleagues [107] showed that the presence of gut microbes was associated with decreased fecal miRNA expression, although specific miRNAs were not examined. Also working with stool samples, but utilizing qRT-PCR and a specific set of four miRNAs known to be expressed in intestinal epithelial cells, Moloney and colleagues [108] showed that conventional mice produced higher levels of three of the four miRNAs (let-7b, miR-141, and miR-200a) than germ-free mice. Interestingly, when they utilized an antibiotic-treated rat model, all four miRNAs showed lower levels of expression after 6 weeks of antibiotic treatment, but at 2 weeks, half were upregulated and half were downregulated, suggesting a temporal nature to the antibiotic effect on miRNA expression. The potential functional consequences of these changes were not examined and are difficult to predict as let-7b functions as an anti-oncomiRNA (miRNAs that inhibit proto-oncogenes) and $m i R-141$ and $m i R-200 a$ function as oncomiRNAs in CRC [109-111].

By deleting Dicer, a protein that is required for miRNA processing, Liu and colleagues [107] showed that intestinal epithelial cells, goblet cells, and Paneth cells each contribute to miRNA production, whereas lymphocytes do not. Other studies have examined intestinal epithelial cells directly to ensure that the observed miRNA differences were caused by the effect of gut microbes on epithelial cells alone. Using microarray and qPCR data, Nakata and colleagues [112] showed that miR-21-5p is expressed at higher levels in the small and large intestines of conventional mice than in germ-free mice. They then went on to show that exposing HT-29 and SW480 cells (two CRC cell lines) to heat-killed Bacteroides acidifaciens type A43 and to Lactobacillus johnsonii 129 resulted in an upregulation of $m i R-21-5 p$, suggesting that molecules derived from these bacteria (and not live bacteria alone) can directly regulate the expression of this well-studied oncomiRNA [112]. Paradoxically, both of these bacteria are regarded as probiotic bacteria and not oncogenic [113, 114], again indicating the need for studies focused on functional outcomes. Peck and colleagues [115] took their analysis a step further by isolating various epithelial cell subtypes from jejunal tissue of germ-free mice and of germ-free mice reconstituted with gut microbes for 2 weeks (conventionalized mice). They identified 11 miRNAs that were differentially expressed when all intestinal epithelial cell types were combined, and 19 miRNAs that were differentially expressed only in intestinal epithelial stem cells (IESCs), the cell type that showed the greatest change in miRNA expression. Although the majority of miRNAs showed increased expression in conventionalized mice compared to germfree mice, the most highly expressed miRNA in IESCs (miR-375-3p) showed decreased expression, and knockdown of this particular miRNA in enteroids resulted in increased cellular proliferation [115]. Interestingly, miR-375-3p is downregulated in CRC tissues [116]. Thus, to date, several studies have shown that gut microbes can alter the expression of miRNAs, particularly those that are implicated in CRC development, but few studies have demonstrated a functional impact of these expression changes on tumor development in CRC models.

Following up on that idea, $\mathrm{Yu}$ and colleagues [117] used global miRNA expression profiling to identify several miRNAs that were downregulated in $F$. nucleatumrich tumor samples from patients with recurrent CRC. These authors then treated CRC cell lines with inhibitors of two of these miRNAs (miR-4802 and miR-18a*) and were able to demonstrate increased resistance to two common chemotherapy drugs used to treat CRC, oxaliplatin and 5-FU. By contrast, transfection of the same cells with miRNAs miR-4802 and miR-18a* resulted in decreased drug resistance. Finally, a CRC xenograft model was used to demonstrate that $F$. nucleatum causes resistance to oxaliplatin and 5-FU by downregulating $m i R-4802$ and $m i R-18 a^{*}$ [117]. This is the most systematic example yet of how gut microbes might interact with CEC miRNAs to modulate CRC progression, and it should be used as a model for the future investigation of other CRC-associated gut microbes and miRNAs.

Less is known about the interaction between lncRNAs and the gut microbiome, probably because of difficulties in identifying the function of most lncRNAs. In one study, Dempsey and colleagues [118] found that the expression of lncRNAs in the mouse duodenum, jejunum, ileum, and colon was altered in the absence of gut microbes. Most of the DNA sequences encoding these lncRNAs were located in intergenic regions or in the introns of protein-coding genes, and the IncRNAs were 
predicted to function in regulating the expression of those genes. In the colon specifically, genes related to transforming growth factor (TGF) signaling and G-protein-coupled receptor (GPCR) signaling were identified. Liang and colleagues [119] examined the change in lncRNA expression that occurs when germ-free mice are reconstituted with normal mouse microbiota or with $E$. coli alone. Interestingly, the two different types of microbiome reconstitution resulted in fairly distinct changes in lncRNA signatures with only $8 \%$ overlap (six lncRNAs). These six lncRNAs were not associated with genes, but the authors did note that they are highly expressed in the thymus and spleen, suggesting a potential role in immunity [119].

Notably, the study by Liang and colleagues [119] was conducted using a publicly available database of microarray data. This research strategy can be used to further the field of gut microbiome-lncRNA interactions by mining data from other RNA-sequencing studies that disregarded lncRNAs in their analysis, or that analyzed lncRNAs in conjunction with protein-coding genes. For example, Peck and colleagues [115] identified 1157 protein-coding genes and lncRNAs that were upregulated or downregulated in the IESCs of conventional mice when compared to those of germ-free mice [115]. The genes that were elevated in conventional mice were involved in processes such as 'mitotic cell cycle' and 'nuclear division', suggesting a role in cell proliferation and potentially CRC progression. These data should be further examined to determine whether IncRNAs show the same or a different pattern when analyzed alone.

\section{Mechanistic insights}

Figure 1 provides an overview of the mechanisms by which bacterial communities and species might impact the CEC genome or epigenome, thus altering tumor initiation, growth, and metastasis. An understanding of these mechanisms is necessary to develop creative approaches for the prevention, detection, and treatment of CRC. Most studies to date have examined the effects of changing the microbial community by using either antibiotics or germ-free mice, but only a few have studied the effects of specific bacteria. These studies show that altering the microbial community has a large impact on DNA methylation, histone modifications, and ncRNA expression patterns. The effects on broad categories of genes, such as those involved in cell proliferation, WNT signaling, maintenance of the innate mucosal barrier, generation of reactive oxygen species, ephrin signaling, or TGF- $\beta$ signaling, have been shown by several groups.

Moreover, the patterns of methylation and promoter or enhancer histone marks in genes that are often dysregulated in CRC (such as Arid1b, Cdkn2a, Daxx, Gata3, Map3k1, Notch1, Pten, Smad2, Hoxa5, Polg, Runx1, Runx3, CD37, Stx11, Tceb2, Lgr6, Cdx1, and Fut4) and the expression of miRNAs such as miR-375-3p, miR-21, $m i R-182$, and $m i R-503$ have been shown to be modulated by the gut microbiome. It is tempting to link changes in the gut microbiome to CRC-related pathways exclusively, but it is imperative that we recognize the wide range and sometimes contradictory effects on CECs that are elicited by these organisms. The diverse genes that are altered by gut microbes range from those involved in metabolism and signaling to those functioning in bacterial recognition and immune surveillance; most of these genes have not been linked to CRC development.

Notably, many of the studies that identified CRC-related genes or pathways that are modified by the gut microbiome were not designed to examine CRC-related effects specifically. For example, Kelly and colleagues [94] sought to identify genes altered by the gut microbiome that showed different patterns of H3K4 methylation in individuals with inflammatory bowel disease, but these genes also relate to CRC because similar biological processes are disrupted in the two diseases. Similar to the computational analysis conducted by Liang and colleagues [119], in which microarray data (from a single laboratory) were reanalyzed to look for lncRNA changes induced by the gut microbiome, or the meta-analysis conducted by Drewes and colleagues [7], in which combined data from several groups were reanalyzed through a single computational pipeline, studies examining the impact of the gut microbiome on the epigenome should be reanalyzed to probe for CRC-related alterations that were not explored in the original analyses. Such reanalyses would enhance our understanding of how frequently gut microbes induce epigenomic changes in genes that are related to CRC. There are clear technological hurdles that make this approach challenging. For example, the studies mentioned above utilize several different methods to probe the epigenome, hindering direct cross-comparisons. With ongoing computational advances, analytical pipelines continue to evolve and an expectation of standardized methods appears unlikely. Nonetheless, reanalysis of differing, often small, genomic or epigenomic datasets using a single computational approach may have value in discerning signals and generating new hypotheses for further testing [7].

Once CRC-related genes that are consistently altered by the gut microbiome are identified, we can begin to assess their role in tumor development more systematically. Studies by Donohoe and colleagues [85] exemplify how an AOM/ DSS model of CRC can be used to explore the effect of gut microbial composition or organization on tumor development, with subsequent analysis of the CEC epigenome and genome changes that contribute to tumorigenesis. For example, colon tumors can be analyzed using many different techniques, including ChIP-seq, RNA-seq, DNase-seq, microarrays, and reduced representation bisulfite sequencing 


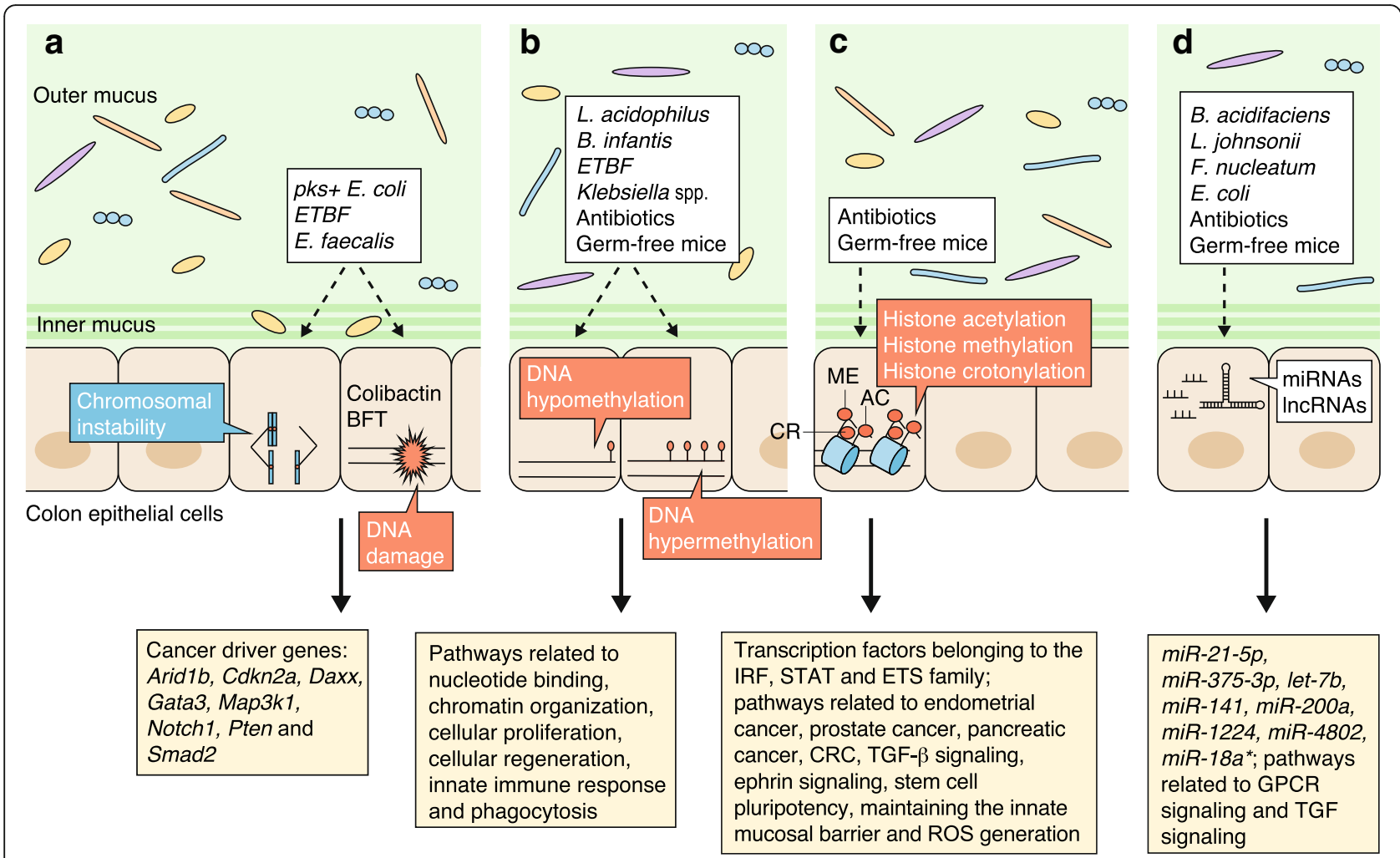

Fig. 1 Effect of the gut microbiome on the colon epithelial cell genome and epigenome. a Enterotoxigenic Bacteroides fragilis (ETBF) and pks + Escherichia coli cause DNA damage in CECs that is mediated by B. fragilis toxin (BFT) and colibactin, respectively. Enterococcus faecalis, through impact on macrophages, induces chromosomal instability and tumor-inducing DNA mutations in cancer driver genes. b Antibiotics, germ-free mice, and specific microbes (Bifidobacterium infantis, Lactobacillus acidophilus, Klebsiella species, and ETBF) have been used to show that gut microbes induce both the hypermethylation and the hypomethylation of genes belonging to pathways that are dysregulated in colorectal cancer (CRC). c Antibiotics and germ-free mice have been used to show that gut microbes do not generally affect global chromatin structure in CECs, but do cause changes in the accessibility of transcription factor binding sites, in histone modifications, and in the location of those modified histones. These modifications often affect the promoter and enhancer regions of genes that belong to pathways that are dysregulated in CRC. d Antibiotics, germ-free mice, and specific microbes (Bacteroides acidifaciens, Lactobacillus johnsonii, and Fusobacterium nucleatum) have been used to show that gut microbes alter the expression of oncomiRNAs and anti-oncomiRNAs in CECs. They also alter the expression of long non-coding RNAs (IncRNAs) that are involved in G protein-coupled receptor (GPCR) and transforming growth factor (TGF) signaling. Abbreviations: ETS e26 transformation-specific, IRF interferon regulatory factor, miRNA microRNA, ROS reactive oxygen species, STAT signal transducer and activator of transcription

(RRBS). Studies by Wang and colleagues [63] typify how a mouse xenograft model can be used to investigate the mutagenic capacity and tumorigenic potential of specific microbes in vitro. As technology advances, we may soon be able to simulate gut microbiome-CEC interactions in vitro and to investigate the impact of modulating microbial communities in a xenograft model $[120,121]$. Studies by O'Hagan and colleagues [122] illustrate how genetic mouse models of CRC can be used to examine changes in the epigenome of tumors that are induced directly by gut microbes. Furthermore, studies by Maiuri and colleagues [61] demonstrate how genetic mouse models of DNA damage pathways can be combined with genetic mouse models of CRC to determine whether specific microbes contribute to tumorigenesis through an accumulation of DNA mutations that would normally be repaired by well-characterized DNA damage repair pathways.
The microbiome community needs to marshal toward the utilization of diverse strategies to identify specific microbes, communities, and mechanisms governing genetic and epigenetic changes that can be targeted to enhance the screening, prevention, or treatment of CRC. Although recent studies have identified an association between both fungi and viruses in the gut and CRC development [123, 124], no specific impacts on CECs or their genomes or epigenomes have been described yet, providing additional opportunities for discovery.

\section{Conclusions and future directions}

One clear goal moving forward is to explore how microbes can be used to better prevent CRC. Bacteria might act directly to impact CRC pathogenesis via the effect of one or more virulence factors on CECs, or indirectly via the production of secondary metabolites or 
the induction of immune changes in the mucosal environment; but how the immune system alters the genome or epigenome of CECs remains a gap in knowledge. As a result, if convincing data accrue that show that bacteria or bacterial communities directly influence colon carcinogenesis, then we may be able to target these bacteria for elimination from the colon via bacteriophage microbiome modulation or targeted antibiotics, or perhaps even develop protective vaccines against them or their virulence determinants. In this approach, the effect of gut microbes on the genome or epigenome of CECs could be utilized to monitor the effectiveness of the vaccine or bacterial elimination strategies, ensuring that other bacteria have not emerged to fill the niche left by the eliminated microbes and thus reduced the effectiveness of these prevention strategies.

Alternatively, bacteria- and gut microbe-induced genetic or epigenetic changes may also be included in approaches for early detection of CRC. Several studies have begun to assess the usefulness of including gut microbes in screening modalities for CRC but, to date, the performance metrics of such approaches limits their utility as clinically relevant screening strategies [9, 10, 125-127]. By contrast, screening strategies that utilize blood to detect mutated genes in cancer (including CRC) are rapidly developing into potentially viable tests [128], and strategies utilizing miRNAs and other epigenetic changes are being carefully considered $[68,129,130]$. It seems possible that the overall sensitivity and specificity of these screening modalities will be enhanced by including the specific gut microbes that contribute to the genetic or epigenetic changes being monitored, or by including gut microbes that are known to be associated with CRC in general.

Gut microbe-induced genetic or epigenetic changes may also inform the development of novel strategies for therapy. Bullman and colleagues [19] showed that Fusobacterium and other associated gut microbiome species were present in primary and metastatic human CRC. They also showed that primary CRC tumors were more readily transplanted into $n u / n u$ mice if the tumor contained Fusobacterium species, and that the implanted tumors retained viable $F$. nucleatum, as well as other anaerobic species, including $B$. fragilis, for longer than 6 months [19]. In these experiments, the tumors grew more slowly when antibiotics were given to the mice after xenograft transplantation, but the authors did not identify the specific effect of $F$. nucleatum on tumors or determine whether addressing the downstream effect of bacterial presence (for example, stable epigenetic changes) might work synergistically with bacterial eradication to enhance tumor elimination. Overall, these data suggest that bacterial species contribute to tumor growth and metastasis, and that bacterial elimination might enhance a CRC treatment scheme, although it seems unlikely that bacterial elimination alone will halt disease progression given the clonal expansion of mutated CECs that defines CRC. The data produced by $\mathrm{Yu}$ and colleagues [117] complement the results of Bullman and colleagues [19] by showing that either removal of $F$. nucleatum or modulation of miRNA expression negated the consequences of bacterial presence in tumors, as tumor responsiveness to chemotherapy was potentially restored.

Overall, understanding and corralling knowledge of the microbiome to thwart disease and to augment disease therapy are towering cross-disciplinary goals. In a time when combination strategies are being implemented to address many diseases, both gut microbes and the genetic or epigenetic alterations that they induce are certain to add value to current targets for the prevention, detection, and treatment of CRC. As CRC is one of the diseases currently being studied most extensively in its connection to the microbiome, translational advancement in this field seems poised to spur progress in other microbiome-associated diseases.

\section{Abbreviations}

AOM: Azoxymethane; BFT: Bacteroides fragilis toxin; CEC: Colon epithelial cell; CIN: Chromosomal instability; CRC: Colorectal cancer; DMR: Differentially methylated region; DSS: Dextran sodium sulfate; ETBF: Enterotoxigenic Bacteroides fragilis; $\mathrm{H}_{2} \mathrm{~S}$ : Hydrogen sulfide; HDAC: Histone deacetylase; IESC: Intestinal epithelial stem cell; SCFA: Short chain fatty acid

\section{Funding}

This work was supported by the Bloomberg Philanthropies (CLS), the Johns Hopkins Department of Medicine (CLS), and Howard Hughes Medical Institute (JA).

\section{Authors' contributions}

$J A$ and CLS both contributed to the writing of this article. Both authors read and approved the final manuscript.

\section{Competing interests}

CLS is supported, in part, by a grant from Bristol-Myers Squibb; JA declares that he has no competing interests.

\section{Publisher's Note}

Springer Nature remains neutral with regard to jurisdictional claims in published maps and institutional affiliations.

Published online: 25 February 2019

References

1. Mulle JG, Sharp WG, Cubells JF. The gut microbiome: a new frontier in autism research. Curr Psychiatry Rep. 2013;15:337.

2. Greenblum S, Turnbaugh PJ, Borenstein E. Metagenomic systems biology of the human gut microbiome reveals topological shifts associated with obesity and inflammatory bowel disease. Proc Natl Acad Sci U S A. 2012;109:594-9.

3. Dejea CM, Wick EC, Hechenbleikner EM, White JR, Mark Welch JL, Rossetti BJ, et al. Microbiota organization is a distinct feature of proximal colorectal cancers. Proc Natl Acad Sci U S A. 2014;111:18321-6.

4. Wang T, Cai G, Qiu Y, Fei N, Zhang M, Pang X, et al. Structural segregation of gut microbiota between colorectal cancer patients and healthy volunteers. ISME J. 2012;6:320-9.

5. Feng Q, Liang S, Jia H, Stadlmayr A, Tang L, Lan Z, et al. Gut microbiome development along the colorectal adenoma-carcinoma sequence. Nat Commun. 2015;6:6528.

6. Nakatsu G, Li X, Zhou H, Sheng J, Wong SH, Wu WKK, et al. Gut mucosal microbiome across stages of colorectal carcinogenesis. Nat Commun. $2015 ; 6: 8727$. 
7. Drewes JL, White JR, Dejea CM, Fathi P, lyadorai T, Vadivelu J, et al. Highresolution bacterial 16S rRNA gene profile meta-analysis and biofilm status reveal common colorectal cancer consortia. NPJ Biofilms Microbiomes. 2017;3:34.

8. Flemer B, Warren RD, Barrett MP, Cisek K, Das A, Jeffery IB, et al. The oral microbiota in colorectal cancer is distinctive and predictive. Gut. 2018:67:1454-63.

9. Zackular JP, Rogers MAM, Ruffin MT, Schloss PD. The human gut microbiome as a screening tool for colorectal cancer. Cancer Prev Res. 2014;7:1112-21.

10. Baxter NT, Ruffin MT, Rogers MAM, Schloss PD. Microbiota-based model improves the sensitivity of fecal immunochemical test for detecting colonic lesions. Genome Med. 2016;8:37.

11. Viljoen KS, Dakshinamurthy A, Goldberg P, Blackburn JM. Quantitative profiling of colorectal cancer-associated bacteria reveals associations between Fusobacterium spp., enterotoxigenic Bacteroides fragilis (ETBF) and clinicopathological features of colorectal cancer. PLoS One. 2015:10:e0119462.

12. Boleij A, Hechenbleikner EM, Goodwin AC, Badani R, Stein EM, Lazarev MG, et al. The Bacteroides fragilis toxin gene is prevalent in the colon mucosa of colorectal cancer patients. Clin Infect Dis. 2015;60:208-15.

13. Ulger Toprak N, Yagci A, Gulluoglu BMM, Akin MLL, Demirkalem P, Celenk T, et al. A possible role of Bacteroides fragilis enterotoxin in the aetiology of colorectal cancer. Clin Microbiol Infect. 2006;12:782-6.

14. Bonnet M, Buc E, Sauvanet P, Darcha C, Dubois D, Pereira B, et al. Colonization of the human gut by E. coli and colorectal cancer risk. Clin Cancer Res. 2014;20:859-67.

15. Buc E, Dubois D, Sauvanet P, Raisch J, Delmas J, Darfeuille-Michaud A, et al. High prevalence of mucosa-associated E coli producing cyclomodulin and genotoxin in colon cancer. PLoS One. 2013;8:e56964.

16. Kostic AD, Chun E, Robertson L, Glickman JN, Gallini CA, Michaud M, et al. Fusobacterium nucleatum potentiates intestinal tumorigenesis and modulates the tumor-immune microenvironment. Cell Host Microbe. 2013;14:207-15.

17. Kostic AD, Gevers D, Pedamallu CS, Michaud M, Duke F, Earl AM, et al. Genomic analysis identifies association of Fusobacterium with colorectal carcinoma. Genome Res. 2012;22:292-8.

18. Castellarin M, Warren RL, Freeman JD, Dreolini L, Krzywinski M, Strauss J, et al. Fusobacterium nucleatum infection is prevalent in human colorectal carcinoma. Genome Res. 2012;22:299-306.

19. Bullman S, Pedamallu CS, Sicinska E, Clancy TE, Zhang X, Cai D, et al. Analysis of Fusobacterium persistence and antibiotic response in colorectal cancer. Science. 2017;358:1443-8.

20. Flanagan L, Schmid J, Ebert M, Soucek P, Kunicka T, Liska V, et al. Fusobacterium nucleatum associates with stages of colorectal neoplasia development, colorectal cancer and disease outcome. Eur J Clin Microbiol Infect Dis. 2014;33:1381-90.

21. Boleij A, van Gelder MMHJ, Swinkels DW, Tjalsma H. Clinical importance of Streptococcus gallolyticus infection among colorectal cancer patients: systematic review and meta-analysis. Clin Infect Dis. 2011;53:870-8.

22. Boleij A, Tjalsma $H$. The itinerary of Streptococcus gallolyticus infection in patients with colonic malignant disease. Lancet Infect Dis. 2013;13:719-24.

23. Baxter NT, Zackular JP, Chen GY, Schloss PD. Structure of the gut microbiome following colonization with human feces determines colonic tumor burden. Microbiome. 2014;2:20.

24. Wong SH, Zhao L, Zhang X, Nakatsu G, Han J, Xu W, et al. Gavage of fecal samples from patients with colorectal cancer promotes intestinal carcinogenesis in germ-free and conventional mice. Gastroenterology. 2017; 153:1621-33.

25. Arthur JC, Perez-Chanona E, Muhlbauer M, Tomkovich S, Uronis JM, Fan T-JT-J, et al. Intestinal inflammation targets cancer-inducing activity of the microbiota. Science. 2012;338:120-3.

26. Arthur JC, Gharaibeh RZ, Mühlbauer M, Perez-Chanona E, Uronis JM McCafferty J, et al. Microbial genomic analysis reveals the essential role of inflammation in bacteria-induced colorectal cancer. Nat Commun. 2014;5:4724

27. Wu S, Rhee K-JJ, Albesiano E, Rabizadeh S, Wu X, Yen H-RR, et al. A human colonic commensal promotes colon tumorigenesis via activation of $\mathrm{T}$ helper type 17 T cell responses. Nat Med. 2009;15:1016-22.

28. Kumar R, Herold JL, Schady D, Davis J, Kopetz S, Martinez-Moczygemba M, et al. Streptococcus gallolyticus subsp gallolyticus promotes colorectal tumor development. PLoS Pathog. 2017;13:e1006440.
29. Housseau F, Wu S, Wick EC, Fan H, Wu X, Llosa NJ, et al. Redundant innate and adaptive sources of IL17 production drive colon tumorigenesis. Cancer Res. 2016;76:2115-24.

30. Thiele Orberg E, Fan H, Tam AJ, Dejea CM, Destefano Shields CE, Wu S, et al The myeloid immune signature of enterotoxigenic Bacteroides fragilisinduced murine colon tumorigenesis. Mucosal Immunol. 2017;10:421-33.

31. Chung L, Thiele Orberg E, Geis AL, Chan JL, Fu K, DeStefano Shields CE, et al. Bacteroides fragilis toxin coordinates a pro-carcinogenic inflammatory cascade via targeting of colonic epithelial cells. Cell Host Microbe. 2018;23:203-14

32. Rubinstein MR, Wang $X$, Liu W, Hao Y, Cai G, Han YW. Fusobacterium nucleatum promotes colorectal carcinogenesis by modulating E-cadherin/ B-catenin signaling via its FadA adhesin. Cell Host Microbe. 2013;14:195-206.

33. Geis AL, Fan H, Wu X, Wu S, Huso DL, Wolfe JL, et al. Regulatory T-cell response to enterotoxigenic Bacteroides fragilis colonization triggers IL17-dependent colon carcinogenesis. Cancer Discov. 2015;5:1098-109.

34. Timp W, Feinberg AP. Cancer as a dysregulated epigenome allowing cellular growth advantage at the expense of the host. Nat Rev Cancer. 2013:13:497-510.

35. Fearon ER, Vogelstein B. A genetic model for colorectal tumorigenesis. Cell. 1990;61:759-67.

36. Lennard KS, Goosen RW, Blackburn JM. Bacterially-associated transcriptional remodelling in a distinct genomic subtype of colorectal cancer provides a plausible molecular basis for disease development. PLoS One. 2016;11:e0166282

37. Hale VL, Jeraldo P, Chen J, Mundy M, Yao J, Priya S, et al. Distinct microbes, metabolites, and ecologies define the microbiome in deficient and proficient mismatch repair colorectal cancers. Genome Med. 2018;10:78.

38. Purcell RV, Visnovska M, Biggs PJ, Schmeier S, Frizelle FA. Distinct gut microbiome patterns associate with consensus molecular subtypes of colorectal cancer. Sci Rep. 2017;7:11590

39. Mima K, Nishihara R, Oian ZR, Cao Y, Sukawa Y, Nowak JA, et al. Fusobacterium nucleatum in colorectal carcinoma tissue and patient prognosis. Gut. 2016;65:1973-80.

40. Burns MB, Montassier E, Abrahante J, Priya S, Niccum DE, Khoruts A, et al. Colorectal cancer mutational profiles correlate with defined microbial communities in the tumor microenvironment. PLoS Genet. 2018;14:e1007376.

41. Francescone R, Hou V, Grivennikov SI. Microbiome, inflammation, and cancer. Cancer J. 2014;20:181-9.

42. Chen J, Pitmon E, Wang K. Microbiome, inflammation and colorectal cancer. Semin Immunol. 2017;32:43-53.

43. Irrazábal T, Belcheva A, Girardin SE, Martin A, Philpott DJ. The multifaceted role of the intestinal microbiota in colon cancer. Mol Cell. 2014;54:309-20.

44. Ye J, Wu W, Li Y, Li L. Influences of the gut microbiota on DNA methylation and histone modification. Dig Dis Sci. 2017;62:1155-64.

45. Bhat Ml, Kapila R. Dietary metabolites derived from gut microbiota: critical modulators of epigenetic changes in mammals. Nutr Rev. 2017;75:374-89.

46. Mischke M, Plösch T. The gut microbiota and their metabolites: potential implications for the host epigenome. Adv Exp Med Biol. 2016;902:33-44.

47. O'Keefe SJD. Diet, microorganisms and their metabolites and colon cancer. Nat Rev Gastroenterol Hepatol. 2016;13:691-706.

48. Paul B, Barnes S, Demark-Wahnefried W, Morrow C, Salvador C, Skibola C, et al. Influences of diet and the gut microbiome on epigenetic modulation in cancer and other diseases. Clin Epigenetics. 2015;7:112.

49. Bultman SJ. Interplay between diet, gut microbiota, epigenetic events, and colorectal cancer. Mol Nutr Food Res. 2017:61:1500902.

50. Louis P, Hold GL, Flint HJ. The gut microbiota, bacterial metabolites and colorectal cancer. Nat Rev Microbiol. 2014;12:661-72.

51. Knudson AG Jr. Mutation and cancer: statistical study of retinoblastoma. Proc Natl Acad Sci U S A. 1971;68:820-3.

52. Fearon ER. Molecular genetics of colorectal cancer. Annu Rev Pathol. 2011;6:479-507

53. Lengauer C, Kinzler KW, Vogelstein B. Genetic instability in colorectal cancers. Nature. 1997;386:623-7.

54. Wood LD, Parsons DW, Jones S, Lin J, Sjoblom T, Leary RJ, et al. The genomic landscapes of human breast and colorectal cancers. Science. 2007:318:1108-13.

55. Nougayrede J-P, Homburg S, Taieb F, Boury M, Brzuszkiewicz E, Gottschalk G, et al. Escherichia coli induces DNA double-strand breaks in eukaryotic cells. Science. 2006;313:848-51. 
56. Cuevas-Ramos G, Petit CR, Marcq I, Boury M, Oswald E, Nougayrede J-P. Escherichia coli induces DNA damage in vivo and triggers genomic instability in mammalian cells. Proc Natl Acad Sci U S A. 2010;107:11537-42.

57. Bossuet-Greif N, Vignard J, Taieb F, Mirey G, Dubois D, Petit C, et al. The colibactin genotoxin generates DNA interstrand cross-links in infected cells. MBio. 2018;9:e02393-17.

58. Maréchal A, Zou L. DNA damage sensing by the ATM and ATR kinases. Cold Spring Harb Perspect Biol. 2013;5. https://doi.org/10.1101/ cshperspect.a012716

59. Dejea CM, Fathi P, Craig JM, Boleij A, Taddese R, Geis AL, et al. Patients with familial adenomatous polyposis harbor colonic biofilms containing tumorigenic bacteria. Science. 2018;359:592-7.

60. Maddocks ODK, Scanlon KM, Donnenberg MS. An Escherichia coli effector protein promotes host mutation via depletion of DNA mismatch repair proteins. MBio. 2013;18(4):e00152-13.

61. Maiuri AR, Peng M, Sriramkumar S, Kamplain CM, DeStefano Shields CE, Sears $C L$, et al. Mismatch repair proteins initiate epigenetic alterations during inflammation-driven tumorigenesis. Cancer Res. 2017;77:3467-78.

62. Johnson GE. Mammalian cell HPRT gene mutation assay: test methods. Methods Mol Biol. 2012;817:55-67.

63. Wang $X$, Yang $Y$, Huycke MM. Commensal bacteria drive endogenous transformation and tumour stem cell marker expression through a bystander effect. Gut. 2015;64:459-68.

64. Pikor L, Thu K, Vucic E, Lam W. The detection and implication of genome instability in cancer. Cancer Metastasis Rev. 2013;32:341-52.

65. Gorgoulis VG, Vassiliou L-VF, Karakaidos P, Zacharatos P, Kotsinas A, Liloglou T, et al. Activation of the DNA damage checkpoint and genomic instability in human precancerous lesions. Nature. 2005;434:907-13.

66. Szikriszt B, Póti Á, Pipek O, Krzystanek M, Kanu N, Molnár J, et al. A comprehensive survey of the mutagenic impact of common cancer cytotoxics. Genome Biol. 2016;17:99.

67. Boot A, Huang MN, Ng AWT, Ho S-C, Lim JQ, Kawakami Y, et al. In-depth characterization of the cisplatin mutational signature in human cell lines and in esophageal and liver tumors. Genome Res. 2018;28:654-65.

68. Okugawa Y, Grady WM, Goel A. Epigenetic alterations in colorectal cancer: emerging biomarkers. Gastroenterology. 2015;149:1204-25.

69. Feinberg AP, Vogelstein B. Hypomethylation distinguishes genes of some human cancers from their normal counterparts. Nature. 1983:301:89-92.

70. Gama-Sosa MA, Slagel VA, Trewyn RW, Oxenhandler R, Kuo KC, Gehrke CW, et al. The 5-methylcytosine content of DNA from human tumors. Nucleic Acids Res. 1983;11:6883-94.

71. Esteller M. Epigenetics in cancer. N Engl J Med. 2008;358:1148-59.

72. Baylin SB, Jones PA. A decade of exploring the cancer epigenome-biological and translational implications. Nat Rev Cancer. 2011;11:726-34.

73. Pan X, Gong D, Nguyen DN, Zhang X, Hu Q, Lu H, et al. Early microbial colonization affects DNA methylation of genes related to intestinal immunity and metabolism in preterm pigs. DNA Res. 2018;25:287-96.

74. Cortese R, Lu L, Yu Y, Ruden D, Claud EC. Epigenome-microbiome crosstalk: a potential new paradigm influencing neonatal susceptibility to disease. Epigenetics. 2016;11:205-15.

75. Yu D-H, Gadkari M, Zhou Q, Yu S, Gao N, Guan Y, et al. Postnatal epigenetic regulation of intestinal stem cells requires DNA methylation and is guided by the microbiome. Genome Biol. 2015;16:211.

76. Pan W-H, Sommer F, Falk-Paulsen M, Ulas T, Best P, Fazio A, et al. Exposure to the gut microbiota drives distinct methylome and transcriptome changes in intestinal epithelial cells during postnatal development. Genome Med. 2018;10:27.

77. Wippermann A, Klausing S, Rupp O, Albaum SP, Büntemeyer H, Noll T, et al. Establishment of a CpG island microarray for analyses of genome-wide DNA methylation in Chinese hamster ovary cells. Appl Microbiol Biotechnol. 2014;98:579-89.

78. Wippermann A, Rupp O, Brinkrolf K, Hoffrogge R, Noll T. Integrative analysis of DNA methylation and gene expression in butyrate-treated $\mathrm{CHO}$ cells. J Biotechnol. 2017;257:150-61.

79. Wei YB, Melas PA, Wegener G, Mathe AA, Lavebratt C. Antidepressant-like effect of sodium butyrate is associated with an increase in TET1 and in 5-hydroxymethylation levels in the Bdnf gene. Int J Neuropsychopharmacol. 2015;18. https://doi.org/10.1093/ijnp/pyu032.

80. Sarkar S, Abujamra AL, Loew JE, Forman LW, Perrine SP, Faller DV. Histone deacetylase inhibitors reverse $\mathrm{CpG}$ methylation by regulating DNMT1 through ERK signaling. Anticancer Res. 2011;31:2723-32.
81. Dawson MA, Kouzarides T. Cancer epigenetics: from mechanism to therapy. Cell. 2012;150:12-27.

82. Zhang J, Ng S, Wang J, Zhou J, Tan S-H, Yang N, et al. Histone deacetylase inhibitors induce autophagy through FOXO1-dependent pathways. Autophagy. 2015;11:629-42.

83. Bultman SJ. Molecular pathways: gene-environment interactions regulating dietary fiber induction of proliferation and apoptosis via butyrate for cancer prevention. Clin Cancer Res. 2014;20:799-803.

84. Belcheva A, Irrazabal T, Robertson SJ, Streutker C, Maughan H, Rubino S, et al. Gut microbial metabolism drives transformation of Msh2-deficient colon epithelial cells. Cell. 2014;158:288-99.

85. Donohoe DR, Holley D, Collins LB, Montgomery SA, Whitmore AC, Hillhouse $A$, et al. A gnotobiotic mouse model demonstrates that dietary fiber protects against colorectal tumorigenesis in a microbiota- and butyrate-dependent manner. Cancer Discov. 2014:4:1387-97.

86. Camp JG, Frank CL, Lickwar CR, Guturu H, Rube T, Wenger AM, et al. Microbiota modulate transcription in the intestinal epithelium without remodeling the accessible chromatin landscape. Genome Res. 2014;24:1504-16.

87. Davison JM, Lickwar CR, Song L, Breton G, Crawford GE, Rawls JF. Microbiota regulate intestinal epithelial gene expression by suppressing the transcription factor hepatocyte nuclear factor 4 alpha. Genome Res. 2017;27:1195-206.

88. Friedrich K, Dolznig H, Han X, Moriggl R. Steering of carcinoma progression by the YIN/YANG interaction of STAT1/STAT3. Biosci Trends. 2017;11:1-8.

89. Sizemore GM, Pitarresi JR, Balakrishnan S, Ostrowski MC. The ETS family of oncogenic transcription factors in solid tumours. Nat Rev Cancer. 2017;17:337-51.

90. Yanai $H$, Negishi $H$, Taniguchi T. The IRF family of transcription factors: inception, impact and implications in oncogenesis. Oncoimmunology. 2012:1:1376-86.

91. Richards AL, Burns MB, Alazizi A, Barreiro LB, Pique-Regi R, Blekhman R, et al. Genetic and transcriptional analysis of human host response to healthy gut microbiota. mSystems. 2016;1:e00067-16.

92. Thaiss CA, Levy M, Korem T, Dohnalová L, Shapiro H, Jaitin DA, et al. Microbiota diurnal rhythmicity programs host transcriptome oscillations. Cell. 2016;167:1495-510.

93. Krautkramer KA, Kreznar JH, Romano KA, Vivas El, Barrett-Wilt GA, Rabaglia ME, et al. Diet-microbiota interactions mediate global epigenetic programming in multiple host tissues. Mol Cell. 2016;64:982-92.

94. Kelly D, Kotliar M, Woo V, Jagannathan S, Whitt J, Moncivaiz J, et al. Microbiota-sensitive epigenetic signature predicts inflammation in Crohn's disease. JCI Insight. 2018;3. https://doi.org/10.1172/jci.insight.122104.

95. Tan M, Luo H, Lee S, Jin F, Yang JS, Montellier E, et al. Identification of 67 histone marks and histone lysine crotonylation as a new type of histone modification. Cell. 2011;146:1016-28.

96. Fellows R, Denizot J, Stellato C, Cuomo A, Jain P, Stoyanova E, et al. Microbiota derived short chain fatty acids promote histone crotonylation in the colon through histone deacetylases. Nat Commun. 2018;9:105.

97. Kita Y, Yonemori K, Osako Y, Baba K, Mori S, Maemura K, et al. Noncoding RNA and colorectal cancer: its epigenetic role. J Hum Genet. 2017:62:41-7.

98. Eulalio A, Schulte L, Vogel J. The mammalian microRNA response to bacterial infections. RNA Biol. 2012;9:742-50.

99. McKenna LB, Schug J, Vourekas A, McKenna JB, Bramswig NC, Friedman JR, et al. MicroRNAs control intestinal epithelial differentiation, architecture, and barrier function. Gastroenterology. 2010;139:1654-64.

100. Geisler S, Coller J. RNA in unexpected places: long non-coding RNA functions in diverse cellular contexts. Nat Rev Mol Cell Biol. 2013;14:699-712.

101. Diosdado B, van de Wiel MA, Terhaar Sive Droste JS, Mongera S, Postma C, WJHJ M, et al. MiR-17-92 cluster is associated with 13q gain and c-myc expression during colorectal adenoma to adenocarcinoma progression. Br J Cancer. 2009;101:707-14.

102. Li L, Sarver AL, Khatri R, Hajeri PB, Kamenev I, French AJ, et al. Sequential expression of miR-182 and miR-503 cooperatively targets FBXW7, contributing to the malignant transformation of colon adenoma to adenocarcinoma. J Pathol. 2014;234:488-501.

103. Li Y, Lauriola M, Kim D, Francesconi M, D'Uva G, Shibata D, et al. Adenomatous polyposis coli (APC) regulates miR17-92 cluster through $\beta$-catenin pathway in colorectal cancer. Oncogene. 2016;35:4558-68.

104. Mogilyansky E, Rigoutsos I. The miR-17/92 cluster: a comprehensive update on its genomics, genetics, functions and increasingly important and numerous roles in health and disease. Cell Death Differ. 2013;20:1603-14. 
105. Luo J, Qu J, Wu D-K, Lu Z-L, Sun Y-S, Qu Q. Long non-coding RNAs: a rising biotarget in colorectal cancer. Oncotarget. 2017;8:22187-202.

106. Sommer F, Nookaew I, Sommer N, Fogelstrand P, Bäckhed F. Site-specific programming of the host epithelial transcriptome by the gut microbiota. Genome Biol. 2015;16:62.

107. Liu S, da Cunha AP, Rezende RM, Cialic R, Wei Z, Bry L, et al. The host shapes the gut microbiota via fecal microRNA. Cell Host Microbe. 2016;19:32-43.

108. Moloney GM, Viola MF, Hoban AE, Dinan TG, Cryan JF. Faecal microRNAs: indicators of imbalance at the host-microbe interface? Benef Microbes. 2018:9:175-83.

109. Cekaite L, Eide PW, Lind GE, Skotheim Rl, Lothe RA. MicroRNAs as growth regulators, their function and biomarker status in colorectal cancer. Oncotarget. 2016;7:6476-505.

110. To KK, Tong CW, Wu M, Cho WC. MicroRNAs in the prognosis and therapy of colorectal cancer: from bench to bedside. World J Gastroenterol. 2018;24:2949-73.

111. Strubberg AM, Madison BB. MicroRNAs in the etiology of colorectal cancer: pathways and clinical implications. Dis Model Mech. 2017:10:197-214.

112. Nakata K, Sugi Y, Narabayashi H, Kobayakawa T, Nakanishi Y, Tsuda M, et al. Commensal microbiota-induced microRNA modulates intestinal epithelial permeability through the small GTPase ARF4. J Biol Chem. 2017;292:15426-33.

113. Bereswill S, Ekmekciu I, Escher U, Fiebiger U, Stingl K, Heimesaat MM. Lactobacillus johnsonii ameliorates intestinal, extra-intestinal and systemic pro-inflammatory immune responses following murine Campylobacter jejuni infection. Sci Rep. 2017;7:2138.

114. Yang J-Y, Lee Y-S, Kim Y, Lee S-H, Ryu S, Fukuda S, et al. Gut commensal Bacteroides acidifaciens prevents obesity and improves insulin sensitivity in mice. Mucosal Immunol. 2017;10:104-16.

115. Peck BCE, Mah AT, Pitman WA, Ding S, Lund PK, Sethupathy P. Functional transcriptomics in diverse intestinal epithelial cell types reveals robust microRNA sensitivity in intestinal stem cells to microbial status. J Biol Chem. 2017;292:2586-600.

116. Xu L, Li M, Wang M, Yan D, Feng G, An G. The expression of microRNA-375 in plasma and tissue is matched in human colorectal cancer. BMC Cancer. 2014;14:714

117. Yu T, Guo F, Yu Y, Sun T, Ma D, Han J, et al. Fusobacterium nucleatum promotes chemoresistance to colorectal cancer by modulating autophagy. Cell. 2017;170:548-63.

118. Dempsey J, Zhang A, Cui JY. Coordinate regulation of long non-coding RNAs and protein-coding genes in germ-free mice. BMC Genomics. 2018;19:834.

119. Liang L, Ai L, Qian J, Fang J-Y, Xu J. Long noncoding RNA expression profiles in gut tissues constitute molecular signatures that reflect the types of microbes. Sci Rep. 2015;5:11763.

120. Shah P, Fritz JV, Glaab E, Desai MS, Greenhalgh K, Frachet A, et al. A microfluidics-based in vitro model of the gastrointestinal human-microbe interface. Nat Commun. 2016;7:11535.

121. Park G-S, Park MH, Shin W, Zhao C, Sheikh S, Oh SJ, et al. Emulating host-microbiome ecosystem of human gastrointestinal tract in vitro. Stem Cell Rev Rep. 2017;13:321-34.

122. O'Hagan HM, Wang W, Sen S, DeStefano SC, Lee SS, Zhang YW, et al. Oxidative damage targets complexes containing DNA methyltransferases, SIRT1, and Polycomb members to promoter CpG islands. Cancer Cell. 2011;20:606-19.

123. Coker OO, Nakatsu G, Dai RZ, Wu WKK, Wong SH, Ng SC, et al. Enteric fungal microbiota dysbiosis and ecological alterations in colorectal cancer. Gut. 2018. https://doi.org/10.1136/gutjnl-2018-317178.

124. Nakatsu G, Zhou H, Wu WKK, Wong SH, Coker OO, Dai Z, et al. Alterations in enteric virome are associated with colorectal cancer and survival outcomes. Gastroenterology. 2018;155:529-41.

125. Liang Q, Chiu J, Chen Y, Huang Y, Higashimori A, Fang J, et al. Fecal bacteria act as novel biomarkers for noninvasive diagnosis of colorectal cancer. Clin Cancer Res. 2017;23:2061-70.

126. Yu J, Feng Q, Wong SH, Zhang D, Liang QY, Qin Y, et al. Metagenomic analysis of faecal microbiome as a tool towards targeted non-invasive biomarkers for colorectal cancer. Gut. 2017;66:70-8.

127. Sze MA, Schloss PD. Leveraging existing 16S rRNA gene surveys to identify reproducible biomarkers in individuals with colorectal tumors. MBio. 2018:9:e00630-18.
128. Cohen JD, Li L, Wang Y, Thoburn C, Afsari B, Danilova L, et al. Detection and localization of surgically resectable cancers with a multi-analyte blood test. Science. 2018;359:926-30.

129. Ahmed FE. miRNA as markers for the diagnostic screening of colon cancer. Expert Rev Anticancer Ther. 2014;14:463-85.

130. Hibner G, Kimsa-Furdzik M, Francuz T. Relevance of microRNAs as potential diagnostic and prognostic markers in colorectal cancer. Int J Mol Sci. 2018;19. https://doi.org/10.3390/ijms19102944.

131. Takahashi K, Sugi Y, Nakano K, Tsuda M, Kurihara K, Hosono A, et al. Epigenetic control of the host gene by commensal bacteria in large intestinal epithelial cells. J Biol Chem. 2011;286:35755-62.

132. Dalmasso G, Nguyen HTT, Yan Y, Laroui H, Charania MA, Ayyadurai S, et al. Microbiota modulate host gene expression via microRNAs. PLoS One. 2011;6:e19293.

133. Archambaud C, Sismeiro O, Toedling J, Soubigou G, Bécavin C, Lechat $P$, et al. The intestinal microbiota interferes with the microRNA response upon oral Listeria infection. MBio. 2013;4:e00707-13.

134. Archambaud C, Nahori M-A, Soubigou G, Bécavin C, Laval L, Lechat P, et al. Impact of lactobacilli on orally acquired listeriosis. Proc Natl Acad Sci U S A. 2012;109:16684-9.

135. Singh N, Shirdel EA, Waldron L, Zhang R-H, Jurisica I, Comelli EM. The murine caecal microRNA signature depends on the presence of the endogenous microbiota. Int J Biol Sci. 2012;8:171-86.

136. Goodwin AC, Destefano Shields CE, Wu S, Huso DL, Wu X, Murray-Stewart TR, et al. Polyamine catabolism contributes to enterotoxigenic Bacteroides fragilisinduced colon tumorigenesis. Proc Natl Acad Sci U S A. 2011;108:15354-9.

137. Vizcaino MI, Crawford JM. The colibactin warhead crosslinks DNA. Nat Chem. 2015:7:411-7.

138. Wang X, Yang Y, Moore DR, Nimmo SL, Lightfoot SA, Huycke MM 4-hydroxy-2-nonenal mediates genotoxicity and bystander effects caused by Enterococcus faecalis-infected macrophages. Gastroenterology. 2012;142:543-51.

139. Wang $X$, Yang $Y$, Huycke MM. Commensal-infected macrophages induce dedifferentiation and reprogramming of epithelial cells during colorectal carcinogenesis. Oncotarget. 2017:8:102176-90. 